\title{
News versus Opinion: The State, the Press, and the Northern Enlightenment
}

\author{
Ellen Krefting
}

The absolutist kingdom of Denmark-Norway may have been situated on the geographical as well as the cultural outskirts of eighteenth-century Europe, but this twin kingdom nonetheless took part in the transformation and expansion of news transmission at the beginning of the Enlightenment period. Handwritten newsletters, printed broadsheets, pamphlets and ballads began circulating early in the seventeenth century. Networks of postal routes were connected directly and regularly to several European networks through Hamburg, a centre for the dissemination of news about Europe and beyond. These networks made possible the first newspapers regularly printed in Copenhagen, which were published from the 166 os in German and Danish. ${ }^{1}$ The popular craze for news became a literary topic early in the eighteenth century, just as in other, more central parts of Europe. The market for news, however, and for printed material in general, developed and expanded despite the heavy controls imposed by the Lutheran, absolutist state through the privilege system and strict censorship laws and procedures.

Absolutism was introduced in 166o, with a Royal Law (Kongeloven) vesting all legislative, executive, judicial and fiscal power in the sovereign king. The market for print was placed under even stricter control in order to protect absolutist power and religious uniformity. Scholars have traditionally seen absolutism as the main reason for the centralised and slow development of the printed news press, especially in the Norwegian part of the kingdom during most of the eighteenth century. As we shall see, the official censorship 'rescript', issued by the king in 1701, laid particularly detailed and comprehensive constraints on the news press, explicitly prohibiting the blending of 'news'

1 For an analysis of the Scandinavian news press in the seventeenth century, see Paul Ries, 'The Politics of Information in Seventeenth-Century Scandinavia', in Brendan Dooley and Sabrina Baron (eds.), The Politics of Information in Early Modern Europe (London: Routledge, 2001), pp. $237-272$. 
on the one hand, defined as "what is reported to really have taken place", with 'opinion', or what it called 'reasoning' or 'conjectures', on the other. ${ }^{2}$

In this chapter, I aim to show that concerns beyond the political were involved in the sharp distinction between news and opinion that was articulated in the censorship instruction. I will argue that the structure of the media landscape in eighteenth-century Denmark-Norway was shaped by the controlling state which based its conception of news - as distinct from opinion - also on epistemological worries concerning the reliability of truth claims which haunted all of Europe at the time. I will raise the question of whether this distinction had only repressive effects and will try to show how the 'censorship rescript' of 1701 can be said to have contributed productively to shaping not only the book market, but the entire media landscape in eighteenth-century Denmark-Norway. My contention is that the sharp distinction between news and opinion opened a favourable space for the medium of the journals, turning the craze for news into what was referred to at the time as a fast-spreading 'writing disease', an urge to express one's own knowledge and opinion on a variety of matters. As a consequence, the journals, rather than the news press, became the vehicle for the phenomenon that we can call the 'Northern Enlightenment'.

\section{Literacy and Censorship}

"The Danish and Norwegian absolutist hereditary Monarch is hereafter to be looked upon and honoured by all subjects as the brightest and most elevated Head on our Earth, and to be above all manmade Laws ..., accountable to no one but God". 3 So announced the 1665 Lex Regia, Europe's only formal absolutist constitution. But long before this foundation of absolutism, the government aimed to build a Lutheran state composed of pious and obedient subjects. One important vehicle for streamlining religious and intellectual life was literacy. As Charlotte Appel has demonstrated, the 'Catechism policy' of the seventeenth-century church strongly promoted literacy. ${ }^{4}$ Luther's Shorter

2 The 'Censur-Instrucs' is reprinted in its entirety in P.M. Stolpe, Dagspressen i Danmark, dens Vilkaar og Personer indtil Midten af det attende Aarhundrede , 4 vols. (Copenhagen: 18781882), I, pp. 348-355.

3 Paragraph II of Kongeloven 1665, here quoted from Lex Regia: or the royal law of Denmark. Writ in the Danish language by order of Frederick III. Of Denmark, Norway, of the Goths and Vandals, etc. Subscribed by his Majesty on the 4th day of November 1665. Translated into English by a lover of the British constitution (London: 1731).

4 Charlotte Appel, Leesning og bogmarked i 16oo-tallets Danmark, 2 vols. (Copenhagen: Museum Tusculanums forlag, 2001). 
Catechism was seen as the essence of Christian faith; the reading of the text had to be the basis and the starting point for all Christians. This boosted exceptionally high literacy all over Scandinavia during the seventeenth and eighteenth centuries. ${ }^{5}$ This holds true even for peasants in the more remote parts of the Norwegian realm, as book historian Jostein Fet has shown. ${ }^{6}$ Reading was the path to salvation and to obedience, which explains why the Dano-Norwegian post-Reformation government actively sought to make pious reading material available on the market. But reading could also pave the road to damnation and social unrest. ${ }^{7}$ The other important vehicle for streamlining religious and intellectual life was therefore close control of the market for print, especially the production and circulation of print material among the general population. To protect the population from heresies and distortions - and the state and the church from opposition and social conflict - the state implemented censorship laws and practices as well as monopolies and privileges that regulated print.

Absolutism further promoted the process of political centralisation and intellectual universalisation, strengthening requirements for schooling and for desirable printed material, ranging from religious literature to political texts supportive of the government. The institution of pre-publication censorship itself dated back to the reformation, but it became no less important and meticulously played out with absolutism. Censorship was control of communication; it was supposed to protect the secrecy and privacy of policy making and to exclude any printed expression incongruent with or subversive of the monarchy and the Lutheran church. At the same time, the censorship system secured the verticality of communication between king and subjects. The government made royal decisions publicly known so that subjects could see, understand and obey them. On the other hand, individual subjects were allowed to pass petitions and suggestions directly to the king, as a kind of private communication from below, hidden from the public. The state sought to maintain loyalty and obedience by creating the impression of a benevolent and merciful

5 See Loftur Guttormsson, 'The Development of Popular Religious Literacy in the Seventeenth and Eighteenth Centuries', Scandinavian Journal of History, 15:1-2 (1990), pp. 7-35; Egil Johansson, The History of Literacy in Sweden in Comparison with Some Other Countries (Umeå: Umeå University and Umeå School of Education, 1977).

6 Jostein Fet, Lesande bønder. Littercer kultur i norske allmugesamfunn for 1840 (Oslo: Universitetsforlaget, 1995).

7 See Elisabeth L. Eisenstein, Divine Art, Infernal Machine: The Reception of Printing in the West from First Impressions to the Sense of an Ending (Philadelphia: University of Pennsylvania Press, 2011) for a general European overview of this duality. 
king who generously granted personal and financial favours. ${ }^{8}$ The possibility of horizontal, mass communication among subjects, however, was extremely limited. Censorship was aimed at obstructing political and religious discussion as well as criticism and the formation of what would be frequently discussed in the later eighteenth century as 'the general voice' or 'public opinion'. 9

The Danish Law and the Norwegian Law promulgated in the 1680 s provided the framework for the organisation of both theological and political prepublication censorship. ${ }^{10}$ Printers and booksellers needed royal privilege, and they were only allowed to publish and disseminate texts that had also obtained approbation - in the form of what was called imprimatur - by an official censor. The approbation signalled that the text did not contain anything that challenged or insulted their Majesties or the Church. People responsible for printed material dishonouring the king could face torture and execution. This applied not only to domestic publications, but also to imported material. ${ }^{11}$

The appointed censors were university faculty members from the relevant fields; texts on matters of religion were censored by the theology faculty, and secular texts - including scientific, historical and literary works - by the appropriate professor from the philosophy faculty. Texts on politics and economics were singled out for special attention; censorship in this domain was entrusted only to a select few government officials. In the censorship process, adjustments could be made in how a text or parts of a text were categorised. As Jakob Maliks has noted, significant shifts in categorisation occasionally occurred, revealing deep changes in world view and conceptions of truth. ${ }^{12}$ An important

8 See Michael Bregnsbo, 'The Crisis and Renewal of the Monarchy: Introduction', in Pasi Ihalainen et al.(eds.), Scandinavia in the Age of Revolution: Nordic Political Cultures, 1740-1820 (Farnham: Ashgate, 2011), pp. 17-28; Jakob Maliks, 'To Rule is to Communicate. The Absolutist System of Political Communication in Denmark-Norway 1660-1750', in Ellen Krefting, Aina Nøding and Mona Ringvej (eds.), Eighteenth-Century Periodicals as Agents of Change. Perspectives on Northern Enlightenment (Leiden: Brill, 2015), pp. 134-152.

9 The Dano-Norwegian expressions circulating in periodicals in the latter part of the eighteenth century were 'Publikums Røst', 'Den offentlige Stemme', 'Den Almeene Røst', 'Folkets stemme'. See Martin Eide (ed.), Norsk presses historie I. En samfunnsmakt blir til 1660-1880 (Oslo: Universitetsforlaget, 2010), p. 63.

10 The Norwegian Law of 1687 (equally valid for the Danish realm) was particularly detailed about the censorship procedures. See The Norwegian Law of 1687, Book 2, Chapter 20, article 1, 'On books and almanachs'.

11 See Øystein Rian, Sensuren i Danmark-Norge: Vilkårene for offentlige ytringer 1536-1814 (Oslo: Universitetsforlaget, 2014), especially Chapter 4, pp. 150-152.

12 Maliks, 'To Rule is to Communicate', pp. 136-137. The book in question was Johan Brunsmand, En liden, kort og enfolding Erklaring. Om noget Kiøge-Huus-Kaarsis Historie, angaaendis. Dennem til Behag, som elske Sandhed (Copenhagen: 170o). 
turn of this kind can be seen from the debate between the different faculties of the university in 1700 about which academic department should have responsibility for censoring a book that supported the existence of witchcraft. As neither the government nor the theologians at the University of Copenhagen believed in the existence of witchcraft, responsibility was moved from the faculty of theology to the faculty of philosophy.

Printed newspapers, introduced in Denmark-Norway during the first half of the seventeenth century, were considered 'politicum negotium', political texts. ${ }^{13}$ News publications - called 'nye Relationer' or 'Aviser' in Danish (terms covering both popular news pamphlets, which offered single 'complete' stories, and news sheets that presented shorter pieces of information from several places) - were, in the beginning, not considered important enough to merit censorship at the very highest level. In 1644, the censoring responsibility was given to a professor in history. ${ }^{14}$ With the advent of absolutism, however, this authority was at some point taken over by the government itself, probably by the Foreign Ministry ('Det tydske Kancelli'). ${ }^{15}$

The special attention censors gave to news publications in the seventeenth century was first and foremost motivated by a need to keep them from publishing 'implausible and false news'. This is clear from what happened after the outbreak of the war with Sweden in 1644, during which news sheets aired anxieties and rumours. Joachim Moltke and Melchior Martzan, who from 1634 held the privilege to print and sell news broadsheets as well as weekly newspapers in Danish and German, received several official complaints in the spring of 1644 for spreading misinformation. The result was that their publications, which the censors had previously handled lightly, suddenly needed manuscript approval before being printed. ${ }^{16}$ It was not so much the political status of the news that provoked this reaction as their trustworthiness.

\section{'Naked' and Contextualised News in the Seventeenth Century}

The privileges given to publishers during the latter part of the seventeenth century show that newspapers had by then become separated from popular broadsheets, permitting the publishers of newspapers to extract, copy, and

\footnotetext{
13 Stolpe, Dagspressen i Danmark, I, p. 130.

14 According to a decision taken by the University of Copenhagen in July 1644. See Stolpe, Dagspressen i Danmark, I, pp. 130-131.

15 Stolpe, Dagspressen i Danmark, II, pp. 293-294.

16 See Stolpe, Dagspressen i Danmark, I, pp. 128-129.
} 
sometimes translate objective information and present it to their readers. Copenhagen's first newspapers were printed in German and conveyed mainly international news reports that drew heavily on traditional Hamburg newspapers and other foreign sources. ${ }^{17}$ There were strong concerns about the purity of the news and the trustworthiness of the reporting. In 1673 Daniel Paulli, editor of the German-language Copenhagen newspaper Extraordinaires Relationes aus Allerley Orten, responded to such fears by expressing the goal of producing 'naked' news. He echoed the words of his German newspaper hero Georg Greiflinger:

I do not make up the news myself, but communicate it unchanged as it is related to me, first by one, then by another [person], and present it to the public as a naked girl so that everybody can dress her the way he wishes and believe as much of it as he thinks fit. ${ }^{18}$

Yet Paulli (together with an Altona news reporter) was prosecuted after French complaints about anti-French biases in the reports. ${ }^{19}$ As Paul Ries has suggested, this was not due to any personalised, opinionated content, but might simply be explained by Paulli's method of presentation. ${ }^{20}$ Rather than adopting the staccato style of simple reporting, as seen in Gøde's Ordinarie Post-Tidende, for instance, Paulli's newspaper used the traditional principle of rubrics headed by names of the countries covered in the reports they contained. In this way, he provided a more contextualised picture of events.

The first newspaper in Danish, Den danske Mercurius, published monthly from 1666 to 1677 , provided ever more contextualised news overviews and summaries. It offered both national (about one third) and international news in versified form (modelled after the French La muze historique), written and edited by the poet Anders Bording, who had royal privilege and was paid by the king as a government official. Bording's close relations with the new power elite may explain the surprisingly large amount of original, domestic news. Some of this was even quite controversial and politically sensitive, such as the account of the arrest in March 1676 of the ennobled Peder Schumacher Griffenfeld on

\footnotetext{
17 See Ries, 'The Politics of Information'.

18 Quoted in Ries, 'The Politics of Information', p. 261.

19 See Stolpe, Dagspressen i Danmark, II, p. 304.

$20 \quad$ Ries, 'The Politics of Information', p. 253.
} 
suspicion of high treason. ${ }^{21}$ Because of its versified form and its extreme loyalty to the authorities, Den danske Mercurius has often been considered a poetic bagatelle. Yet one of the striking features of this 'official', royal newspaper is the reporter's urge to contextualise: Bording actually combined straight reporting of 'what had actually happened' with commentaries and explanation, mainly with the aim of justifying the king's point of view and his decisions. But he also brought a broader moral dimension to the news. In the Griffenfeld case, for instance, Bording pointed to the relationship between greed and corruption. The editor frequently reminded his readers that not only news and information, but also moral lessons could be learnt from observing the actions of all the players on the world stage. Bording's Den danske Mercurius explicitly used the newspaper as a means of secular reasoning and of influencing readers' views of the world.

\section{The 1701 Censorship Instruction}

In January 1701, the king published an official censorship 'rescript' that put an end to the way Den danske Mercurius and other papers (such as Paulli's Extraordinaires Maanedlige Relationer from 1673) provided monthly news summaries that combined news and commentaries. The rescript officially prohibited the blending of 'news', on the one hand - belonging to the realm of truth and impartiality and defined as 'what is reported to have really taken place' - with opinion or what is called 'reasoning' and 'conjecture' on the other.

The immediate context for the rescript was the outbreak in 1700 of the Great Northern War, which made international news reports - comprising the major part of the content of newspapers - particularly sensitive. There had already been several complaints from foreign powers on the content of Copenhagen newspapers, and the war required even closer control over the press. The official decree, aimed at censors and publishers equally, started by prescribing an extremely cumbersome censorship procedure explicitly targeting the publication of news.

Two crown-appointed censors (soon to be cut to one) from the Home Ministry (det danske Kancelli) were entrusted with the pre-publication censoring of newspapers (both manuscript and printed). The rescript required newspaper

21 Den danske Mercurius 1666-1677, pp. 481-482, available at Arkiv for dansk literatur, www .adl.dk, http://adl.dk/adl_pub/pg/cv/ShowPgImg.xsql?p_udg_id=392\&p_sidenr=13\&hist= \&nnoc=adl_pub. 
editors to scrutinise their sources (mainly foreign newspapers) to ensure that they contained no harmful content. They were then supposed to submit two identical handwritten copies to the censor, for correction and signing off. Leaving one copy of the approved text with the censor, editors then had two copies of it printed. They once again submitted these to the censor. Having checked that both of these printed copies corresponded in every detail to the approved handwritten copy, the censor would again sign both copies and retain one, while the editor was now free to hand the second copy to the printer, who was supposed to print the censored and approved text without changes.

The instructions were equally detailed concerning the material to be excluded: international news not reprinted from foreign newspapers; any remarks questioning the foundations or splendour of the realm or harmful to the interest of the king, ministers or officials; information about size or strength of the nation's army or navy; details of negotiations with foreign powers and 'sceptical, scornful or offensive' remarks about foreign princes or their representatives. It is after this that we find the distinction between pure news and individual opinion:

Also to be excluded is the reasoning of the nouvellistes and others' discourses on what is happening, and similarly unnecessary conjectures about what could possibly happen, and one must only deal with what is reported to really have taken place.

The rescript meticulously listed the type of content that could be included in newspapers: detailed and respectful descriptions of grand occasions, such as processions and feasts, to ensure that no fault could be found by others in the ceremonies of the Danish court; official announcements and royal proclamations; information about shipping and other forms of trade; and advertisements of important auctions or the loss of valuable property. The rescript required that all information must be written in plain language with appropriate vocabulary and published as soon as possible after the arrival of the post, except in the case of monthly newspapers, which were to carry only the most important and recent reports already published during the preceding month and nothing else.

Surely, these censorship procedures, if they were to be followed to the letter, did not enhance the frequency and regularity of the news press. The early circulation of printed news already suffered from irregularities caused by erratic postal services and political vicissitudes. ${ }^{22}$ In periods of war, there

22 The postal instruction of 1694 required postal delivery between Hamburg and Copenhagen twice a week. There were weekly deliveries to Norwegian cities. See Stolpe, Dagspressen i Danmark, II, pp. 247-248. 
could be overloads of information that affected the size, the title and the frequency of newspapers (often coupled with supplements, 'extraordinaires' or appendices). ${ }^{23}$ As P.M. Stolpe has demonstrated in his detailed history of the early press in Denmark-Norway, the two last decades of the seventeenth century had seen the growth of a surprisingly rich and lively news press conveying information and stories of many kinds in many forms. The beginning of the eighteenth century marked a turn towards a news press of a more conscious, rigid and submissive kind. This trend was enforced by the censorship instruction of 1701 .

The immediate motives behind the censorship instruction might well be the particularly sensitive context of the outbreak of war and the need to control public discussions about (international) politics. But the text also expresses quite clearly a more general anxiety concerning the 'purity' of the news and the truth value of its reports.

\section{Truth Worries and News Frenzy}

The epistemological worries following religious conflicts as well as the huge impact of the 'new philosophy' and the 'scientific revolution' have been well documented for decades by scholars of early modern intellectual history who see the heightened sense of urgency and self-consciousness regarding the contingency of truth claims as a defining feature of the late seventeenth and early eighteenth century. ${ }^{24}$ Despite deep changes in evidentiary standards and practices in the period, a growing readership still expressed the problem of interpreting and trusting various truth claims, such as the information conveyed by so-called 'true relations' of different sorts (of fires, heavenly apparitions, women giving birth to animals, as well as of scientific experiments), as Frances E. Dolan has shown in her study of late-seventeenth-century England. ${ }^{25}$ The category of news did not escape these worries about reliability, as Andrew Pettegree has recognised in The Invention of News. ${ }^{26}$ With the expansion of the commercial news market and a larger and more dispersed audience hungry for news, a tide of criticism arose, questioning the trustworthiness and integrity of

23 Stolpe, Dagspressen i Danmark, II, p. 120.

24 See, for example, Paul Hazard, La crise de la conscience européenne, 1680-1715 (Paris: Fayard, 1961); Steven Shapin, A Social History of Truth. Civility and Science in SeventeenthCentury England (Chicago: University of Chicago Press, 1994).

25 Frances E. Dolan, True Relations: Reading, Literature, and Evidence in Seventeenth-Century England (Philadelphia: University of Pennsylvania Press, 2013).

26 Andrew Pettegree, The Invention of News. How the World Came to Know about Itself (New Haven and London: Yale University Press, 2014). 
the news messengers (were they interested parties?) and the verifiability of the information (was it based on pure rumour?), and expressing a growing dissatisfaction with the serial form of news delivery itself. Newspapers were forced to present events that were still unfolding and to include a lot of potentially trivial information, chosen hurriedly from a larger heap of news items. Pettegree shows how critics of the newspaper at the beginning of the eighteenth century complained of 'information overload', and how they worried that the old tradition of straight reporting (with the manuscript newsletter as a norm) was being contaminated by political or commercially biased opinion, analysis and polemics (news pamphlets, in particular). ${ }^{27}$ These anxieties were also connected to a growing concern for the social consequences of the proliferation of a commercialised serial news press. Why should anyone other than public men and merchants need to read newspapers? Was newspaper reading among the general public leading to idleness? And what was happening to truth and good sense when newspapers were resorting to blending facts, fiction, rumours and opinion in order to gain readers?

The anxieties about news reporting and news reading that Dolan and Pettegree have described also apply to the Dano-Norwegian context. We have already seen how the censoring institutions worried about the publication of false news in the printed newspapers of late seventeenth-century DenmarkNorway. The most flamboyant expression of concern about the growing newsreading public is found in the very first comedy written for the Copenhagen stage in 1722 by the Norwegian-born playwright, historian and major intellectual of the period, Ludvig Holberg. The play, called Den politiske kandestøber (The political tinker), mocked and attacked the craze for news and current affairs among ordinary people. It was clearly inspired by the essays from The Tatler about the 'political upholsterer', a figure Steele describes as "the greatest newsmonger", who was "much more inquisitive about what was happening in Poland than in his own family". ${ }^{28}$ Like Steele's 'upholsterer', Holberg's 'tinker' is an honest man - one who happens to have become absorbed by politics. He spends most of his time passionately debating the latest news from southern Europe or local politics, while his family and business are neglected. He is a 'project maker' - a recurring negative characteristic in Holberg's work (as we shall see later). The tinker frequents taverns, where he reads newspapers and exchanges opinions, "knowing everything, and yet nothing", as Holberg himself points out in his introduction to the first published edition of the play. The knowledge these artisans and commoners in the taverns draw from the

27 Pettegree, The Invention of News, especially pp. 261-266.

28 The Tatler, nos. 155, 160 and 178. 
newspapers they read and discuss is superficial, and the information given cannot always be trusted. Holberg also emphasised the untrustworthiness of news in his mock-heroic poem Peder Paars, published just a couple of years earlier (1719). It presents newspaper printers as 'bold liars'.

Holberg's satirical attack targeted not only the moral and levelling effects of the popular appetite for news and politics: an avid, news-craving, politically engaged sector of the society, in which artisans and other would-be politicians try to rise above their station and run society (threatening the natural and rational social hierarchy and the functioning of political culture defended by Holberg). He also directed his satire at the very production and transmission of news. How can we rely on what we read in the newspapers? How can we distinguish news stories (whether they are called 'news', 'reports', 'true relations', 'correspondences', 'intelligences', 'information' or avvisi) from other stories, fact from fiction, or opinion? ${ }^{29}$

As we have already seen, worries about the blending of news with more discursive, analytical and polemical opinion had already been expressed in the 1701 censorship instruction. The absolutist state of Denmark-Norway sought by law and cumbersome censorship procedures to protect unadorned fact in news reporting. As Stolpe and Ries have noted, when followed to the letter, the procedure drastically reduced the speed of the news delivery, which made 'naked' news less fresh. In reality, however, the instruction was not followed to the letter. There were actually long periods when the newspapers in DenmarkNorway did not undergo censorship prior to publication. ${ }^{30}$ This does not necessarily indicate that the regime had adopted a more liberal policy. During the first decades of the eighteenth century, only one printer in Copenhagen had the privilege to publish news in the entire twin kingdom, and there was always the threat of post-publication sanctions. The laws nonetheless served as a constant threat and proved to be an effective spur towards self-censorship. The absolutist regime seems, in fact, to have had only minor problems with

29 'Avis' is today the Norwegian and Danish word for newspaper, but in Holberg's work this was still the name of a specific piece of information about the contemporary world, either local or more geographically distant, often supported by written documentation of some kind or making reference to (living) eyewitnesses, to be assembled and printed in a 'nyhedsblad' or 'relationer'. See the Holbergordbog (the 'Holberg dictionary') at http:// holbergordbog.dk/.

30 Stolpe actually contends that no newspapers until 1738 were censored, and were published at the printer's own risk (Dagspressen i Danmark, II, p. 302). Yet, the censorship instructions were repeated unchanged in the Press rescript of 1756 , when the police were appointed to conduct pre-publication censorship of newspapers. See also Øystein Rian, Sensuren i Danmark-Norge, pp. 172-173. 
the Dano-Norwegian newspapers (with the exception for the newspapers published in the town of Altona, close to the liberal city-state of Hamburg) for decades after 1701, even with the rapidly increasing amount of domestic news they contained.

Press historians agree that the Copenhagen newspapers of the early eighteenth century were loyal and extremely panegyric towards king and court. The information they conveyed was also quite limited to life at court. Disasters, such as the outbreak of a plague in 1711 or the great fire of 1728 were only mentioned briefly. ${ }^{31}$ In delicate matters, such as the reporting of the death of Queen Louise and the king's rapid marriage to Anna Sophie Reventlow in the same issue of Hoftidende ('News from the court') the editor solicited the chancellor (Gehejmeraad) in order to find the right words. ${ }^{32}$ What the licensed newspapers avoided reporting is perhaps the most telling; for instance, the public persecution on 8 March 1723 of the Trondheim-born civil servant and publicist Povel Juel, who was charged with conspiracy and high treason. This was undoubtedly an important and sensational event in Copenhagen, but since it concerned the state and its politics, the newspapers did not take any chances and no Copenhagen newspaper mentioned the event with so much as a single word. The affair, however, was richly described in a popular broadsheet ballad about 'the dreaming prince project maker Povel Juel'. ${ }^{33}$ What was not allowed to appear as 'news' was published as a sensational, contextualised, entertaining story instead - which surely demonstrates that newspapers were not the only conveyers of important information to the public.

\section{News, Announcements and Opinions}

There are good reasons to contend that the 1701 censorship instruction contributed to the meagre content and prosaic but loyal style of the newspapers. It is also possible to argue that the instruction contributed to the shaping of the whole 'media landscape' of Denmark-Norway in the eighteenth century. One characteristic of this landscape is the increasing amount of announcements - advertisements for goods, notifications for objects lost and found - in the newspapers. The handful of serial news publications in German, French

31 Stolpe, Dagspressen i Danmark, II, p. 276.

32 See Stolpe, Dagspressen i Danmark, II, p. 280, and Ellen Krefting, Aina Nøding and Mona Ringvej, En pokkers skrivesyge. 17oo-tallets dansk-norske tidsskrifter mellom sensur og ytringsfrihet (Oslo: Spartacus, 2014), pp. 53-55.

Krefting, Nøding, and Ringvej, En pokkers skrivesyge, p. 55. 
and Danish emanating from Copenhagen continued to carry pieces of political information from abroad in addition to national news from the court and the royal family (according to the instruction from 1701), serving the king's need to exhibit and legitimise his absolute power. ${ }^{34}$ But newspapers were also in the process of becoming channels for local news in the purest, most factual and least sensitive sense, politically speaking.

The very first so-called newspapers published in the Norwegian realm of the twin kingdom were pure intelligencers (Intelligenz-Blätter in German) or 'address newspapers' as they were called in Norwegian, such as Norske IntelligenzSeddeler in Christiania (1763), Efterretninger fra Adresse-Contoiret $i$ Bergen $i$ Norge (1763) and Kongelig allene privilegerede Tronhiem Adresse-Contoirs Efterretninger in Trondheim (1767), later to be known as 'Adresseavisa' (and still today the largest Trondheim newspaper).$^{35}$ All of them followed the model of the Copenhagen Addressekontorets Efterretninger launched by Hans Holck in $1759 .{ }^{36}$ This kind of publication was usually connected to a public office for the exchange of information serving the local trade in goods and services. This phenomenon of a public 'trading post' had spread from France to other European countries during the seventeenth century (the Frenchman Théophile de Renaudot established the first 'Bureau d'adresse' in Paris in 1637). The editors of the Bergen and Trondheim 'address newspapers' had both obtained privileges for establishing address offices. The Christiania intelligencer, however, had circumvented privilege restrictions by not being connected to an office. Samuel Conrad Schwach's printing shop, however, functioned effectively as a public trading post. ${ }^{37}$

All three Norwegian papers avoided strict censorship procedures by shunning the publication of political news. The motives behind these weekly publications were connected to trade, manufacturing and practical interests. The main bulk of material they published were advertisements, notifications of local sales and private services, announcements of property and persons lost and found, personal notices (engagements, marriages, births and obituary notices), announcements of public services and useful, religious essays as well as

34 See Stolpe, Dagspressen i Danmark, II, and Martin Eide (ed.), Norsk presses historie I, pp. 41-55.

35 There had been earlier attempts at publishing a Norwegian newspaper, such as Den Ridende Mercurius in Bergen in 1721, but they were all prohibited by the government in Copenhagen.

36 See Chr. Kirchhoff-Larsen, Den danske presses historie, 3 vols. (Copenhagen: Berlingske, 1942-1962), I, pp. 53-84.

Eide (ed.), Norsk presses historie I, p. 112. 
fictional, entertaining texts (often translated pieces) and anecdotes and letters from readers (a combination first introduced in Germany in 1759). ${ }^{38}$ Schwach in Christiania was particularly eager to adapt his publication to the varying needs and desires of the reading public. Variety in content as well as in form was his motto. He also encouraged his readers to contribute, to the point that the paper was accused of being a post box for reader's manuscripts and of not being properly edited according to textual and social norms. The paper opened its pages for people of humble origins to criticise tradesmen and artisans for overpricing their goods and services. ${ }^{39}$ Hence, Norske Intelligenz-Seddeler was an important medium for non-political, local news in the most 'naked' and factual sense. Yet it also became an important medium for the exchange of ideas and opinions: for public debate. The debates could be bold and stretch over several issues, but they did not concern politics or news directly. They were first and foremost concerned with questions of social norms and civic virtues, and with questions of style and taste.

\section{From 'news frenzy' to 'writing disease'}

The intelligencers, however, were not the only medium for conveying and exchanging local knowledge, personal thoughts and opinions. After 1720, weekly or monthly journals appeared in rising numbers, starting with the learned journal Lcerde efterretninger. Some of these journals were not only licensed, but were even encouraged by the state or edited by royal officials. The most prominent example of a journal the regime saw as useful for the state is the annual journal Danmark og Norges Oeconomiske Magazin (1757-1764). It was the result of a royal invitation in 1755 to people of all strata - "whoever he may be, high or low, aristocrat or not, clerical or not, learned or not; he will be most welcomed" - from every corner of the twin kingdom, to submit "theses of general use in economic and physical matters". It welcomed contributions from periodicals and publications dealing with economic development. ${ }^{40}$ The

38 See Aina Nøding, Vittige kameleoner: Litteræere tekster i norske adresseaviser 1763-1769 (Oslo: Unipub, 2007), p. 25.

39 See Eide (ed.), Norsk presses historie I, pp. 107-123. In fact, the correspondence and debate had characterised this kind of news publication from its beginning in Paris in 1637. See Nøding, Vittige kameleoner, p. 25.

40 Erik Pontoppidan, Indbydelse til at insende almennyttige økonomiske og fysiske Afhandlinger til Grev A.G. Moltke. En Opfordring til at forene sig om Skribentvirksomhed 
magazine - which published "a mixture of small pieces submitted by good patriots concerning the possible perfection of agriculture, foresting, mining, house building, the breeding of livestock, fisheries, manufacturing, etc., in the service of bettering the common good" - was edited by Erik Pontoppidan, the pro-chancellor of the university, and became an important channel for assembling and disseminating knowledge of technology and economics, and for critical discourse about these matters. ${ }^{41}$ It aimed to convey not only more knowledge, but knowledge of increasingly higher quality and relevance, which implied critical discussion. As Maliks has noted, establishing a governmentsubsidised periodical under the supervision of a highly dependable editor somehow resolved the dilemma the government faced concerning the critical discourse on economics. ${ }^{42}$ Economics had previously been one of the subjects not allowed in print, being closely connected to legislation and politics. Now, the government encouraged public discussion, but under its close control.

Not all journals, however, were initiated by the government. The extremely popular spectator journals, also called 'moral weeklies', characterised by having a fictitious narrator presenting essays on a variety of topics, appeared in Denmark-Norway from the 1740 . The genre thrived on the legal, political and epistemological distinction between news and opinion expressed in the 1701 rescript. As we have seen, concern about political news and the heavy restrictions around its publication were, by the middle of the century, supplemented by a controlled interest in public debate about practical, economic matters. But these concerns did not affect publications such as the spectator journals, which specialised exclusively in social observation, secular moral reasoning, philosophical discussion, and personal opinion. As long as the journals steered clear of reporting or commenting on news, and shunned any content that addressed political (or economic) matters directly, they obtained approbation (imprimatur) from the censors. The learned journals and the spectator journals alike were censored by the more liberal and independent professors among the philosophy faculty.

(Copenhagen: 1755), p. 7. See Mona Ringvej, 'Communicative Power and the Absolutist State. Denmark-Norway c. 1750-1800', in Pasi Ihalainen et al. (eds.), Scandinavia in the Age of Revolution, pp. 303-316; Maliks, 'To Rule is to Communicate', pp. 144-146.

It was followed by a growing amount of topographical literature in Denmark-Norway with the continuing production of descriptions of local geography, natural resources, technology, history and folk culture. See Anne Eriksen, Topografenes verden: Fornminner og fortidsforståelse (Oslo: Pax, 2007).

Maliks, 'To Rule is to Communicate', pp. 144-145. 
The relatively open-minded censoring of the 'spectators' appearing in Copenhagen during the 1740 os makes a case for considering censorship in Denmark-Norway at the time as both 'functionally ambiguous' and also 'productive', rather than purely repressive. The learned and literary profile of moral weeklies such as Den danske Spectator (1744-1745) and La Spectatrice danoise ('The female Danish spectator', published in French in Copenhagen from 1748 to 1750 ), with a limited and non-popular readership, probably made them less problematic in the eyes of censor H.P. Anchersen, a professor of history and eloquence at Copenhagen University. These spectator journals were modelled on the English Spectator of Addison and Steele and their German, French and Swedish imitators. The English pioneers had famously mixed the publication of moral essays on 'fixt and immutable' themes with social observation and political news. Such a mix was not possible in the Dano-Norwegian context, where blending news with opinion was forbidden. But both of these journals were bold and experimental in their opinion-based content as well as in style, with their attention to important Enlightenment questions, such as religious liberty, social inequality, the legitimacy of the nobility, the role of women, education and freedom of the press. The authors used the moral weeklies as channels for a new drive to seek the truth by means of secular reasoning, and for their urge to write and communicate from a more modest station in society. ${ }^{43}$ By employing various fictional dialogical forms, they succeeded in creating something resembling a horizontal public sphere in miniature form. They served as forums in which multiple voices could engage in rationalist and sometimes quite critical debates on philosophical and moral as well as social and even political issues. ${ }^{44}$

We know that the censor Anchersen had required changes and revisions before their publication, which is clearly expressed by Jørgen Riis, the author of Den danske Spectator, who exclaimed that "My reflections would have been more useful had it not been necessary to disguise the truth". In the very last issue of his journal he admits that "I have been forced to exclude a lot of important matters ... and I have had to squeeze the juice out of them, just to reach the end of the year with my journal". ${ }^{45}$ But the fact that this journal and also

\footnotetext{
43 Ellen Krefting, 'The Urge to Write: Spectator Journalists Negotiating Freedom of the Press in Denmark-Norway', in Krefting et al. (eds.), Eighteenth-Century Periodicals, pp. 153-171.

44 Jørgen Riis, the author of Den danske Spectator, actually published several spectator journals in parallel (Den danske Anti-Spectator, Den politiske Spectator) during 1744 and 1745, which commented upon each other, creating a fictitious exchange in print. See Krefting, 'The Urge to Write'.

Den danske spectator 38, pp. 349 and 52, p. 468.
} 
Laurent De La Beaumelle's La Spectatrice danoise were licensed at all indicates the level of negotiation that must have been involved between the censor and these authors. Censor Anchersen, being a learned man and author, probably considered himself as a literary guide and guardian of quality rather than as a repressor of literature. His negotiation with the authors may have served the desire to affect and contribute to the literary field in a positive way, making journals like these actually happen, rather than suppressing them. This is 'productive censorship' of a very practical kind, echoing how the French censors of literary publications operated during the Enlightenment, according to Robert Darnton. ${ }^{46}$

The rise and growing success of this particular type of journalism in Denmark-Norway, conveying personal opinion and debate rather than news, did not, however, go unnoticed. Most of the journals like the two mentioned here were short-lived, but they served as a low-threshold medium for a young generation with a growing urge to write and publish their points of view and to become 'authors' in their own right. Several journalists of this kind started commenting on this urge, in their own journals, pointing to a 'writing disease' spreading in the twin kingdom, from Copenhagen to the more remote parts of Norway. In a 1761 issue of his journal Tronhiemske samlinger ('The Trondheim collections'), Peter Frederik Suhm refers - through one of his fictitious characters - to "a goddamn writing disease spreading in this town". A few years later, the phenomenon is registered also in Bergen and other Norwegian towns. In a 1794 issue of Den snaksomme Bergenser ('The chattering citizen of Bergen'), the editor notes self-ironically that 'To be a publicist and to write in public has in our days become an epidemic fever which is spreading quickly among the children of men'. Even people who hardly can read what they write, get to publish their 'original madness', he exclaimed in print. ${ }^{47}$

Yet, the first to link the new journalism to an epidemic illness (of the more serious and destructive kind) had been the elderly author and history professor Ludvig Holberg. Assessing the new opinion-based journalism developing during the 1740s from the outside, not to say from above, he despised it as much as he had loathed the craze for news decades earlier. Holberg had

46 Robert Darnton, Censors at Work: How States Formed Literature (New York: W.W. Norton, 2014). On 'productive censorship' see also Matthew Bunn, 'Reimagining Repression. New Censorship Theory and After', History and Theory, 54 (2015), pp. 25-44.

47 'At ville være offentlig Skribent og skrive offentlig, er i vore Dage blevet en epidemisk feber, som griber alt mer og mer om sig blant Menneskenes Børn', Bernt Børretzen in Den snaksomme Bergenser, no. 41, 1794. See Krefting, Nøding and Ringvej, En pokkers skrivesyge. 
himself frequently argued during his career for greater freedom of expression in print. ${ }^{48}$ Yet he was utterly sceptical of these publicists "from nowhere", rising above their station, trying to "act as authors", as he phrased it at one point in the $1740{ }^{49}$ According to Holberg, the spectator journalists were contaminated by the sudden and dangerous writing disease spreading in the kingdom - threatening the standards of quality in the literary field. Spectator journalists were perfect examples of "project makers", or "political tinkers" who, as he put it, "are quick to hurriedly recast the world in a different mould". They confirmed, Holberg wrote, that "freedom of expression had gone too far". To him, it might seem at times, the world would remain a better place without either news or opinions - especially the news and opinions that engaged common citizens.

In this matter, Holberg was not on history's winning side. Journals like the ones initiated by Riis and La Beaumelle were to become the most important medium for the importation and dissemination of Enlightenment ideas and debates in Denmark-Norway during the latter part of the eighteenth century, slowly transforming the textual, intellectual as well as the political landscape of Denmark-Norway and culminating in the Norwegian liberal constitution of 1814. The newspapers were still singled out for special censorship procedures even under the two-year regime of the royal physician Struensee, who, in the name of the mentally ill king, declared unrestrained freedom of the press in $1770 .{ }^{50}$ However, the journals of the late 178 os and 1790 s, from central to distant towns of Denmark-Norway, were arenas for praise, humour and discussions about the French Revolution, freedom of speech, natural rights, 'democracy' and new constitutions. This lively public sphere of journals may explain how so many people, even peasants from the various Norwegian valleys, displayed a spontaneous urge to participate in the discussions about constitutional matters during the weeks before the signing of the Norwegian Constitution at Eidsvoll in May 1814.51

48 See Krefting, 'The Urge to Write', pp. 160-162.

49 Ludvig Holberg, 'Fortale', in Adskillige Heltinders og navnkundige Damers sammenlignende Historier efter Plutarchi Maade (Copenhagen, 1745). For Holberg's comments on the spectators, see also essay number 280 of his Moralske tanker (Copenhagen, 1744), and epistles number 63, 72, 413 and 478 in Epistler (Copenhagen 1748-1754) both available at http://holbergskrifter.no.

$5^{0}$ See John Christian Laursen, 'Censorship in the Nordic Countries ca. 1750-189o. Transformations in Law, Theory, and Practice', Journal of Modern European History, 3 (2005), pp. 100-117.

See Krefting et al. (eds.), En pokkers skrivesyge, pp. 278-280. 


\section{Journalism and The 'Northern Enlightenment'}

Recent research trends have revised previous notions of the Enlightenment as a unified, intellectually coherent set of ideas or practices originating in France and penetrating other parts of Europe or the world with varying degrees of success. Although it would be equally wrong-headed to evade any 'diffusionist' approach and view the Enlightenment as an intellectual phenomenon determined solely by national context, there is no doubt that 'enlightenment' ideals, visions and practices look different from a Dano-Norwegian perspective. I will conclude with the contention that the state-controlled media landscape of the eighteenth century, with its relatively poor news press but a bourgeoning public sphere of opinions which I have tried to describe in this chapter, can offer a useful vantage point for considering certain characteristics and general features of what we can call the 'Northern Enlightenment'.

At a general level, the Northern Enlightenment is distinguished by Lutheranism, utilitarianism and support of absolutism rather than by anti-religious, democratic radicalism and universalism. It was definitely conservative and 'mainstream', in Jonathan Israel's terms. ${ }^{52}$ Enlightenment discourse in Denmark-Norway was largely disseminated by intellectuals either employed by the absolutist state (clergy, university professors, state officials) or closely tied to state interests. These interests were, during the early eighteenth century, turning from warfare and security to development and welfare. Ideas of material and social growth for the common good were grounded in the economic paradigm of 'cameralism', being the German version of mercantilism which saw detailed state control of economic life as the core of development and public welfare. In its Dano-Norwegian adaptation, this also implied seeing scientific progress and the dissemination of practical and useful knowledge among the population as vital for the state's economic performance. The result was that the new public sphere of print did not emerge from private, 'bourgeois' initiatives, as it did in other parts of Europe, but from the absolutist government actively promoting the development of 'enlightenment' through print.

State-serving publicists saw education and the rise in general knowledge as a means of achieving material and moral 'perfection' and common welfare. The apparently growing appetite for intellectual, religious, legal and social reform, for science and learning and for a flourishing public sphere of

$5^{2}$ See Jonathan Israel, 'Northern Varieties. Contrasting the Dano-Norwegian and the Swedish-Finnish Enlightenments', in Krefting et al. (eds.), Eighteenth-Century Periodicals, p. 17. 
print was permeated by 'patriotism', a moral-political discourse about social improvement and of the common good that nonetheless rarely questioned or opposed the prevailing political and social order. Within these 'patriotic' frames, public discussions about science, philosophy, literature, morality and social norms and even about 'civic liberties' were thriving. Censors were eager to negotiate with the authors and journalists in order to promote knowledge, literature and reasonable opinions. In Denmark-Norway, 'civic liberties' (such as freedom of expression) and 'absolutism' were not seen as mutually incompatible. On the contrary, they were closely interrelated ideals, as the prominent journalist and professor in political sciences Jens Schielderup Sneedorff argued adamantly in his own periodicals. According to his 'patriotic' ideology, royal power and the public sphere are associated in a continuous process of exchange and interdependence that is fundamentally necessary for the state's health. ${ }^{53}$

The fact is, however, that the freedom to express one's own opinions or, even more, to report truthfully and fearlessly what was actually happening in the world was still dependent on whatever was defined as the interests of the state and of the absolutist king. It was not until the Constituent Assembly at Eidsvoll in Norway decided to break with Danish absolutist rule in 1814 that this freedom was guaranteed by constitutional right (within certain limits) in article 100 of the Norwegian constitution. This is also the period in which we see the emergence of a genuine news press in Norway, where daily papers could function as 'political hour watches' or an 'archive of the time'. According to the editor Niels Wulfsberg, his newspaper called Tiden ('The time'), published from 1808, was to offer not only "foreign and domestic news of public interest", but also discussions of "topics about which there can be doubt".54 The trustworthiness of news was no longer something to be decided or controlled by the king. It was to be discussed in the newspapers themselves.

53 See Jens Schielderup Sneedorff, Den patriotiske tilskuer (Copenhagen, 1761-1763) and his treatise Om den Borgerlige Regiering (Copenhagen, 1757).

Quoted from Eide (ed.), Norsk presses historie I, p. 195. 